\title{
Student's perception towards challenges and difficulties to established E-learning Medical Education in a high burden developing country
}

Mohamed D. A. Gismalla ( $D$ mohadaff22@yahoo.com )

University of Gezira

Mohamed Soud Mohamed

University of Gezira

Omaima Salah 0 Ibrahim

University of Gezira

Moawia Mohamed Ali Elhassan

National Cancer Institute University of Gezira

Mohammed Naser Eldeen Mohammed

University of Gezira Faculty of Medicine

Research article

Keywords: E-learning, Distance learning, Medical Education, Africa

Posted Date: December 14th, 2020

DOI: https://doi.org/10.21203/rs.3.rs-46982/v2

License: @ (i) This work is licensed under a Creative Commons Attribution 4.0 International License. Read Full License

Version of Record: A version of this preprint was published at BMC Medical Education on July 10th, 2021. See the published version at https://doi.org/10.1186/s12909-021-02811-8. 


\section{Abstract}

Background: In High-income countries, many academic institutions are using E-learning during COVID 19 Pandemic. However, in limited-resource countries, like Sudan, shifting towards E-learning requires many adjustments to be made in order to make sure the E-learning is held in a proper manner, as best as possible. This study was undertaken to assess medical students' perception towards implementing E-learning during COVID 19 Pandemic and to highlight difficulties of E-learning implementation in Sudan as an example of a limited-resource setting.

Methods: A cross-sectional survey was conducted between 10 and 25 of May 2020 among the undergraduate medical students at the Faculty of Medicine, University of Gezira, Sudan. A predesigned online-based questionnaire was used for data collection and snowball sampling methodology was used.

Results: The total numbers of 358 undergraduate medical students responded to the online survey questionnaire. The majority (87.7\%) of students agreed that the closure of the university is an essential decision to control the spread of the COVID-19 infection. Approximately two-thirds (64\%) of students perceived that E-learning is the best solution during COVID 19 lockdown. The level of students in the university and residence has a strong relation to students' opinion the level of medical students (Pre-clerkship and Clerkship) and place of residence have significant correlation ( $p$-value $<0.05$ ) with medical students opinion regards starting the E-learning online education. Internet bandwidth and connectivity limitation, unfamiliarity with E-learning system, technical support limitation and time flexibility in case of technical problems during online exams, and Lack of face-to-face interaction were the factors considered by medical students to be against the E-learning implementation.

Conclusion: Most medical students had a positive perception of E-learning. However, there are many challenges considered as an inhibitory factor for utilizing electronic technologies for medical education. We recommend that challenges of E-learning in our limited resource setting should be systematically evaluated and that effective strategies should be developed to overcome their inhibitory effects.

\section{Background}

In March 2020 World Health Organization (WHO) declared that, Coronavirus disease 2019 (COVID-19) as a worldwide pandemic.[1] This pandemic is an unprecedented emergency that has affected all global industries, including education.[2]Moreover, as a result of social distancing, the most effective preventative strategy since the emergence of COVID-19, [3] medical educations has been profoundly disturbed as it involves in-person didactic lectures and tutorials, clinical rotation exposure, laboratory experiences, observing and assisting relevant medical and surgical procedures. [4]

In this crisis, the need to encourage E-learning in the modern world of education becomes clear. E-learning platforms can be utilized to deliver lectures remotely at one's convenience. Students can then log in at a scheduled time for discussions, which can be facilitated live using video and audio conferencing. E-learning has a positive effect if the student participates actively. In high-income countries, there is a good experience in 
distance and online learning in health professional education. [5-7] The situation is differing in low- and middle-income countries, few countries have some experiences in online health professional education, mainly in postgraduates training. $[8,9]$ In Sudan, there is limited exposure to E-learning in high education. A limited number of Sudanese universities offer E-learning, such as the Open University of Sudan, which has 18 branches in Sudan and provide E-Learning through educational web sites, live broadcasting (video conferencing), educational discs, Electronic Library, TV channels, and educational radio. Sudan University of Science and Technology offers E-learning for a master's degree in computer-integrated Education. The University of Gezira offers online E-learning for a master's degree in health professional education.

In response to COVID-19, all universities and colleges in Sudan commanded their students to stay home so the government could handle the situation. Consequently, medical training has been invariably affected; however, few private universities have explored the use of online for academic activities. The effectiveness of these learning platforms in Sudan has been questioned because of poor internet connectivity, relatively expensive out-of-pocket spending on internet data bundles, and electricity challenges, especially in remote rural areas. Moreover, lack of experts and limited access to the online platform are other challenges. This survey was conducted to determine the perception of medical students towards E-learning, the effect of COVID1-19 in education. Additionally, we highlight challenges and difficulties.

\section{Methods}

\section{Study types:}

This descriptive cross-sectional survey study was conducted during 10-25 May 2020 among the undergraduate medical students at the Faculty of Medicine, University of Gezira, Sudan to determine the perception of medical students regarding the E-learning, COVID Pandemic, and difficulties to re-establish the educational process.

\section{Study population:}

The study population included any medical students registered at the Faculty of Medicine, University of Gezira. Survey responses were collected anonymously. The research study was granted an exemption by the Ethics committee of the Faculty of medicine, university of Gezira.

\section{Study area:}

The Faculty of Medicine, University of Gezira was established in 1975. It is situated in Wad Medani, the capital of Gezira State. Though the Faculty of Medicine was established in 1975 the first batch of students was enrolled in 1978 and it is the second oldest medical college in Sudan. Currently, there are 42 medical schools in Sudan. The Faculty of Medicine, University of Gezira is the first school to adopt the community-oriented, community-based, and problem-solving strategies in the country and is a pioneer in this innovative type of education all over the globe with social accountability. There has been close collaboration between the World Health Organization and the Medical School since its inception.

\section{Study tools:}


A predesigned online-based questionnaire was developed by the principal investigator. The content accuracy and internal validity of the survey items were finalized with multidisciplinary input from the study investigators. It was then piloted on 10 medical students from outside the study sample and modifications were made according to the suggestions. The questionnaire was composed of 16 questions divided into three sections. All questions were labeled with serial numbers. The data collected included: Demographics (age, sex, residence, class), Attitude toward COVID-19, and Knowledge, experience, and attitude toward online education. The type of questions used included: Yes/No questions, four response questions in a form of strongly agree, agree, disagree, and strongly disagree (modified Likert scale) as well as other open questions regarding factors to implement starting E-learning. The questionnaire was sent to students' email addresses and a brief informed consent stated in the opening of the electronic questionnaire. Participants were invited to share the survey link via social media platforms with other medical students in the faculty of medicine, the university of Gezira through a snowball sampling method.

\section{Data collection and analysis:}

Data were entered and analyzed using SPSS (Statistical Package for Social Science); version 24. Categorical variables are presented as frequencies and percentages and continuous data are presented as means (standard deviation) or median values (range) depending on normality. Chi-square distribution was applied to assess the statistical significance of the effect of sex, level of the student, grade, and residence on knowledge/attitude of starting E-learning. $\mathrm{P}<0.05$ was considered as statistically significant.

\section{Results}

\section{Character of students}

The total number of participants who agreed to participate in is 358 out of 1700 medical undergraduate students. They responded to the survey and filled the electronic questionnaire. The mean age was 20.4 years (SD, 2.07) and ranged between 17-27 years. Female was predominant at $207(57.8 \%)$. The responders were from all over Sudan; even though $57.5 \%$ are from Gezira state and $8.4 \%$ are residents of other countries. In terms of access to computers, $67.9 \%$ of students had laptops, and $88.5 \%$ of them had a smartphone which used to access the internet. The number of respondents blessed by having static internet services was 145 (40.5\%). The other detailed characteristic of the participant was shown in table 1. 
Table 1: Character of students (Participants) N=358

\begin{tabular}{llll}
\hline Variables & & Frequency & \% \\
\hline Gender & Female & 207 & 57.8 \\
& Male & 151 & 42.2 \\
\hline Residence & Inside Sudan inside & 199 & 55.6 \\
& Gezira & & \\
\hline & Inside Sudan outside & 129 & 36.0 \\
& Gezira & & \\
\hline & Outside Sudan & 30 & 8.4 \\
\hline Patches & 37 & 53 & 14,8 \\
\hline & 38 & 37 & 10,3 \\
\hline & 39 & 69 & 19.3 \\
\hline & 40 & 67 & 18,7 \\
\hline & 41 & 53 & 14,8 \\
\hline & 42 & 79 & 22.1 \\
\hline Do you have static Internet service? & No & 145 & 40.5 \\
\hline & Yes & 213 & 59.5 \\
\hline Do you have a laptop? & No & 115 & 32.1 \\
\hline Do you have a smart phone with reasonable & Nos & 243 & 67.9 \\
\hline facility & & 41 & 11.5 \\
\hline
\end{tabular}

\section{Perceptions and opinions of Medical students towards the effect of the COVID-19 pandemic in Education, cessation of education, and restart of the educational process}

The response of medical students regarding their perceptions and opinions towards the effect of the COVID19 pandemic in Education, cessation of education, and restart of the educational process as shown in table 2. Most students (51\%) strongly agree and $31 \%$ agree that the closure of the university is an essential decision to control the spread of the COVID-19 infection. On the other hand, $12.3 \%$ reported that university closure is unnecessary. Approximately two-thirds (64\%) of students agreed that E-learning is the best solution during COVID-19 lockdown. The majority (69.8\%)of surveyed medical students agreed or strongly agreed that this high time to continuing education through E-learning. Approximately two-thirds strongly agree or agree to attend the E-learning sessions and exams during the COVID-19 pandemic. Figure 1 showed a suitable time to start regular learning in the faculty buildings. The level of medical students (Pre-clerkship and Clerkship) and place of residence have significant correlation ( $p$-value $<0.05)$ with their responses to the survey question "If the distant/online education is started soon, you will agree and attend the session and exams?" as shown in table 3. 
Table 2: Perceptions of Medical students towards the effect of the COVID-19 pandemic in Education, cessation of education, and restart of the educational process

\begin{tabular}{|c|c|c|c|c|c|}
\hline & $\begin{array}{l}\text { Strongly } \\
\text { agree }\end{array}$ & Agree & Disagree & $\begin{array}{l}\text { Strongly } \\
\text { disagree }\end{array}$ & $\begin{array}{l}\text { Mean } \\
\text { Likert's } \\
\text { score }\end{array}$ \\
\hline $\begin{array}{l}\text { The closure of university is useful to } \\
\text { prevent COVID-19 }\end{array}$ & $\begin{array}{l}184 \\
(51.4 \%)\end{array}$ & $\begin{array}{l}130 \\
(36.3 \%)\end{array}$ & $\begin{array}{l}29 \\
(8.1 \%)\end{array}$ & $\begin{array}{l}15 \\
(4.2 \%)\end{array}$ & 3.3 \\
\hline $\begin{array}{l}\text { The worldwide closure is useful to prevent } \\
\text { COVID-19 }\end{array}$ & $\begin{array}{l}155 \\
(43.3 \%)\end{array}$ & $\begin{array}{l}171 \\
(47.8 \%)\end{array}$ & $\begin{array}{l}24 \\
(6.7 \%)\end{array}$ & $8(2.2 \%)$ & 3.3 \\
\hline $\begin{array}{l}\text { If the distant/online education is started } \\
\text { soon, you will agree and attend the } \\
\text { session and exam }\end{array}$ & $\begin{array}{l}117 \\
(32.7 \%)\end{array}$ & $\begin{array}{l}124 \\
(34.6 \%)\end{array}$ & $\begin{array}{l}64 \\
(17.9 \%)\end{array}$ & $\begin{array}{l}53 \\
(14.8 \%)\end{array}$ & 2.9 \\
\hline $\begin{array}{l}\text { This is high time Regarding the continuing } \\
\text { education through distant / online } \\
\text { education }\end{array}$ & $\begin{array}{l}74 \\
(20.7 \%)\end{array}$ & $\begin{array}{l}167 \\
(49.2 \%)\end{array}$ & $\begin{array}{l}74 \\
(20.7 \%)\end{array}$ & $\begin{array}{l}34 \\
(9.5 \%)\end{array}$ & 2.7 \\
\hline
\end{tabular}

Table 3: Relations of student's level and Residence to closure of university and start of education / E-Learning

\begin{tabular}{|c|c|c|c|c|c|c|c|c|c|}
\hline & & & \multicolumn{3}{|c|}{ Level of Students } & \multicolumn{4}{|c|}{ Residence of Students } \\
\hline & & total & $\begin{array}{c}\text { Clerk } \\
(\mathrm{n}=90)\end{array}$ & $\begin{array}{c}\text { Pre-clerk } \\
(\mathrm{n}=268)\end{array}$ & $\begin{array}{c}\mathrm{P} \\
\text { value }\end{array}$ & $\begin{array}{l}\text { Inside } \\
\text { Gezira } \\
(\mathrm{n}=199)\end{array}$ & $\begin{array}{l}\text { Outside } \\
\text { Gezira } \\
\text { (n129) }\end{array}$ & $\begin{array}{l}\text { Outside } \\
\text { Sudan } \\
(\mathrm{n}=30)\end{array}$ & $\begin{array}{c}\mathrm{P} \\
\text { value }\end{array}$ \\
\hline $\begin{array}{l}\text { The closure } \\
\text { of university }\end{array}$ & Yes & 314 & $84(93.3)$ & $230(85.8)$ & 0.065 & $177(87.9)$ & $112(86)$ & $25(83.3)$ & 0.491 \\
\hline $\begin{array}{l}\text { is useful to } \\
\text { prevent } \\
\text { COVID }\end{array}$ & No & 44 & 6 & 38 & & 22 & 17 & 5 & \\
\hline $\begin{array}{l}\text { If the } \\
\text { distant/online } \\
\text { education is } \\
\text { started soon, }\end{array}$ & Yes & 241 & $75(83.3)$ & $166(61.9)$ & 0.001 & $130(65.3)$ & $84(65.1)$ & $27(90)$ & $0.002 *$ \\
\hline $\begin{array}{l}\text { you will agree } \\
\text { and attend } \\
\text { the session } \\
\text { and exams? }\end{array}$ & No & 117 & 15 & 102 & & 69 & 45 & 3 & \\
\hline $\begin{array}{l}\text { This is high } \\
\text { time } \\
\text { Regarding } \\
\text { the }\end{array}$ & Yes & 250 & $74(82.2)$ & $176(65.7)$ & 0.02 & $138(69.3)$ & $87(67.4)$ & $25(83.3)$ & 0.227 \\
\hline $\begin{array}{l}\text { continuing of } \\
\text { distant / } \\
\text { online } \\
\text { education }\end{array}$ & No & 108 & 16 & 92 & & 61 & 42 & 5 & \\
\hline
\end{tabular}


However, there are 4 factors considered to be against the E-learning implementation as shown in figure 2. More than one-third (38\%) of the student stated that good quality internet service is expensive, and the Affordable Internet services are poor in quality. Therefore, it difficult to attend live lectures or download media files. Moreover, in certain areas, due to geographical limitations, the telecommunication signal is quite hampered. $24 \%$ reported that they were unfamiliar with E-learning systems. Approximately $40 \%(n=140)$ were concerned about technical support for online sessions and flexibility in case of technical problems during online exams. Eighty-six (24\%) students were concerned about interaction with each other and the instructors during the online session. students.

\section{Discussion}

The COVID-19 outbreak has forced medical schools to suspend campus learning in order to curb the spread of the virus. Currently, medicals schools in Sudan are closed due to the COVID-19 health threat. In such situations, E-learning is the best solution that provides an online interactive learning environment for medical students. Hugenholtzet al. found that E-learning is just as effective in enhancing knowledge as lecture-based learning.[10] In the developed world, many academic institutions are using E-learning for more than twenty years. However, the dominant mode of education around the world is the classic classroom-based interaction. In limited-resource countries, like Sudan, shifting towards E-learning requires many adjustments to be made in order to make sure the E-learning is held in a proper manner, as best as possible.

In the Faculty of Medicine -University of Gezira, undergraduate medical students have no exposure to Elearning. Recently, the Medical Education Development Center-University of Gezira offers On-line E-learning for a master's degree in health professional education. In our study, approximately two-thirds of respondents reported that good quality internet connection is too expensive for them and the affordable bandwidth is limited, which often contributed to slow speed of download and low quality of videos or visual outputs. Moreover, in remote rural areas telecommunication signal is quite hampered. The information on internet infrastructures and the availability of computers in our settings may provide baseline information regards challenges to e-learning implementation. In Sub-Saharan Africa inadequate computer facilities, internet connectivity problems, institute experiences of performing e-learning, poor attitudes among students and lecturers, and incompatibility of mobile devices with the university online management systems. $[11,12] \mathrm{A}$ previous study from India reported that 82 out of 201 of the planned e-learning sessions were canceled due to technical reasons $(20 \%)$ or no availability of the presenter at the host end $(80 \%)$.[13]

We found $24 \%$ of our study population being hostile to accept E-learning for learning because they are unaware of the effectiveness of E-learning compared to the face-face teaching style and are unfamiliar with Elearning systems. Lack of face-to-face interaction was considered as an inhibitory factor for E-learning implementation by $15 \%$ of our study population. Therefore, faculty administrators should develop strategies for increasing and ensuring higher levels of students' engagement in and during E-learning. This challenge was reported in several studies from sub-Saharan Africa. [14-17]

We found most respondents have smartphones with reasonable facilities while only one-third had computers. Therefore, E-learning software that is user-friendly and easy to operate with a smartphone is needed. Mobile Elearning applications have been developed to provide support for students in rural areas. [18, 19]. 
After summarizing the response of students to the open questions, we found that $42.4 \%$ of the respondents were worried that E-learning may need specific preparations. Further study is needed to further investigate what factors considered to make them worried about this topic. If lack of understanding of how the E-learning software runs, it means that the information technology staff must be educating/socializing in more detail to a more limited and specific group. There is also fear among our study population about the methods for online assessment and time flexibility in case of technical problems.

Medical students at the clerk level and those from outside Sudan were more likely to agree to start E-learning and attend the session and exams ( $p$-value $<0.05$ ). This could be because students from outside Sudan (Gulf countries) have access to a good quality internet connection. Further study is needed to explain why medical students at the clerk level were more likely to agree to start e-learning than those in pre-clerkship. To find out the efficacy of E-learning in our limited resource setting, further study is needed to map the examination results of the medical students pre-COVID and compare them to results with E-learning during COVID

The study has several limitations. The small sample size from a single medical school in central Sudan limits the generalizability of our results and the data should be interpreted with caution. Moreover, the sample may not be representative of all medical students as there is a potential for selection bias in distributing via the internet as medical students with access to the internet during the study period were more likely to participate in the study. In this study, data were collected at only one point in time (cross-sectional design) and the researcher could not manipulate the variables. Therefore, longitudinal research is required to enhance the understanding of correlation and interrelationships among variables.

\section{Conclusion}

This study can demonstrate the views of perception regard E-learning among medical students in a limited resource setting after an emergency such as COVID-19. Most medical students have a positive perception of E-learning. However, there are many challenges considered as inhibitory factors for utilizing electronic technologies for medical education. These challenges should be systematically evaluated and that effective strategies should be developed to overcome their inhibitory effects.

\section{Abbreviations}

FMUG: Faculty of Medicine University of Gezira

\section{Declarations}

\section{Ethics approval and consent to participate}

Ethical approval to conduct the study was obtained from the ethical committee of Faculty of Medicine, University of Gezira. Verbal consent was obtained by statement in the beginning of the questionnaire. Participants had been asked to participate and complete the questions, if they are busy or not agreed.

\section{Consent for publication}


Not applicable

\section{Availability of data and materials}

Available upon request

\section{Competing interest}

Authors declare no competing of interest

\section{Funding}

authors declare no fund

\section{Authors' contributions}

MSM, MDAG and MNM conceptualized the study. MSM conducted the data analysis. MMAA conducted the review of literature. MDAG and MMAA prepared the first draft. All authors contributed to review and revision in the first draft and approved the final version.

\section{Acknowledgements}

Authors acknowledge all participants in the study

\section{References}

1. World Health Organization. Coronavirus disease 2019 (COVID-19): situation report, 72.

2. Ayittey FK, Ayittey MK, Chiwero NB, Kamasah JS, Dzuvor C. Economic impacts of Wuhan 2019-nCoV on China and the world. Journal of Medical Virology. 2020 May;92(5):473-5.

3. Tozzi A, D’Amato G. Cross-reactivity between COVID-19 and childhood vaccines? Electronic response to: del Rio C; Malani PN. 2020. 2019 Novel Coronavirus-Important Information for Clinicians. JAMA. Published online February. 2020;5:2020.

4. Rose S. Medical student education in the time of COVID-19. Jama. 2020 Mar 31.

5. ALGAHTANI A. Evaluating the E ectiveness of the E-learning Experience in Some Universities in Saudi Arabia from Male Students' Perceptions.

6. Kim S. The future of e-learning in medical education: current trend and future opportunity. Journal of educational evaluation for health professions. 2006;3.

7. Means B, Toyama Y, Murphy R, Bakia M, Jones K. Evaluation of evidence-based practices in online learning: A meta-analysis and review of online learning studies.

8. Frehywot S, Vovides Y, Talib Z, Mikhail N, Ross H, Wohltjen H, Bedada S, Korhumel K, Koumare AK, Scott $\mathrm{J}$. E-learning in medical education in resource constrained low-and middle-income countries. Human resources for health. $2013 \mathrm{Dec} 1 ; 11(1): 4$. 
9. Frantz JM, Bezuidenhout J, Burch VC, Mthembu S, Rowe M, Tan C, Van Wyk J, Van Heerden B. The impact of a faculty development programme for health professions educators in sub-Saharan Africa: an archival study. BMC medical education. $2015 \mathrm{Dec}$ 1;15(1):28.

10. Hugenholtz NI, De Croon EM, Smits PB, Van Dijk FJ, Nieuwenhuijsen K. Effectiveness of e-learning in continuing medical education for occupational physicians. Occupational Medicine. 2008 Aug 1;58(5):370-2.

11. Adeboye D, van Staden CJ. Difficulties experienced by students using mobile devices to access e-learning. InInternational Conference on Mobile and Contextual Learning 2015 Oct 17 (pp. 351-365). Springer, Cham.

12. Kaliisa R, Picard M. A systematic review on mobile learning in higher education: The African perspective. TOJET: The Turkish Online Journal of Educational Technology. 2017;16(1).

13. Agrawal S, Maurya AK, Shrivastava K, Kumar S, Pant MC, Mishra SK. Training the trainees in radiation oncology with telemedicine as a tool in a developing country: A two-year audit. International Journal of Telemedicine and Applications. 2011 Jan 1;2011.

14. Kheng S. The challenges of upgrading from ISPO Category II level to Bachelor Degree level by distance education. Prosthetics and orthotics international. 2008 Sep;32(3):299-312.

15. Corrêa L, De Campos AC, Souza SC, Novelli MD. Teaching oral surgery to undergraduate students: a pilot study using a Web-based practical course. European Journal of Dental Education. 2003 Aug;7(3):111-5.

16. Akkoyunlu B, Soylu MY. A study of student's perceptions in a blended learning environment based on different learning styles. Journal of Educational Technology \& Society. 2008 Jan 1;11(1):183-93.

17. Muñoz DC, Ortiz A, González C, López DM, Blobel B. Effective e-learning for health professional and medical students: the experience with SIAS-Intelligent Tutoring System. Stud Health Technol Inform. 2010 May 27;156:89-102.

18. Khoja S, Scott RE. Creating e-learning resources in preventive medicine for developing countries. Journal of telemedicine and telecare. 2007 Mar 1;13(2):105-6.

19. Chang AY, Ghose S, Littman-Quinn R, Anolik RB, Kyer A, Mazhani L, Seymour AK, Kovarik CL. Use of mobile learning by resident physicians in Botswana. Telemedicine and e-Health. 2012 Jan 1;18(1):11-3.

\section{Figures}




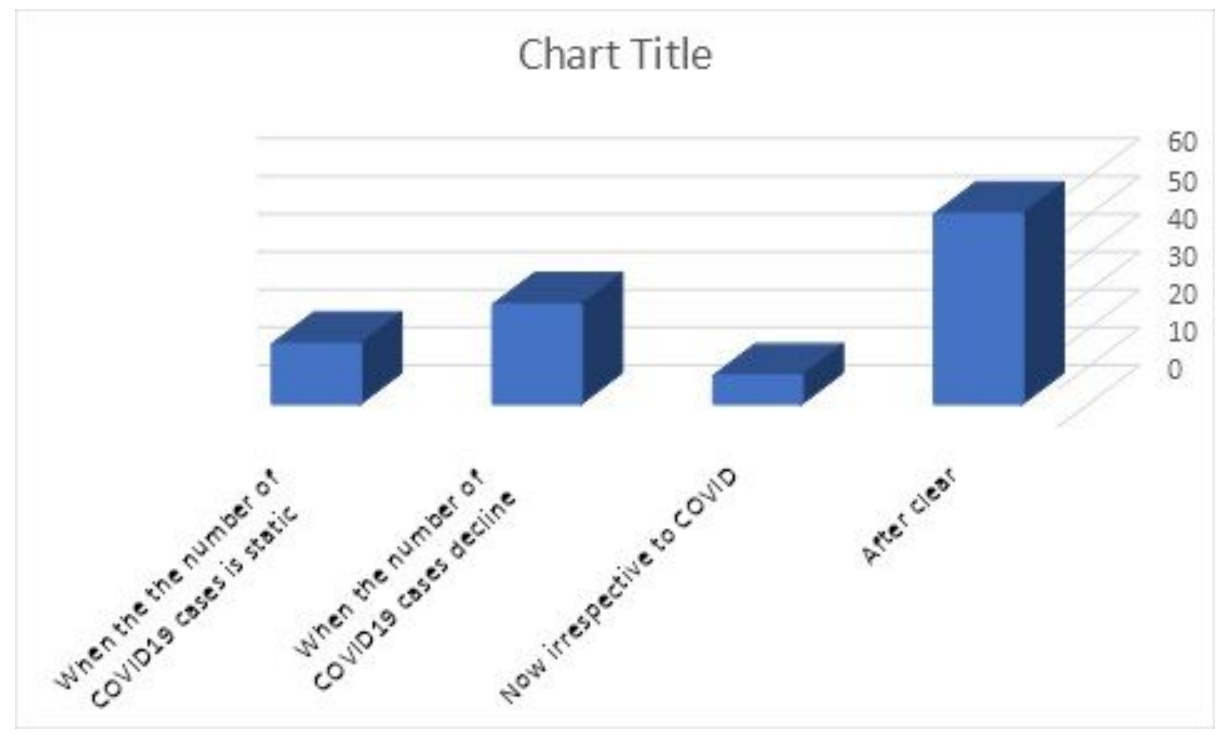

Figure 1

Students view regarding the suitable time to re-start learning process and open the University

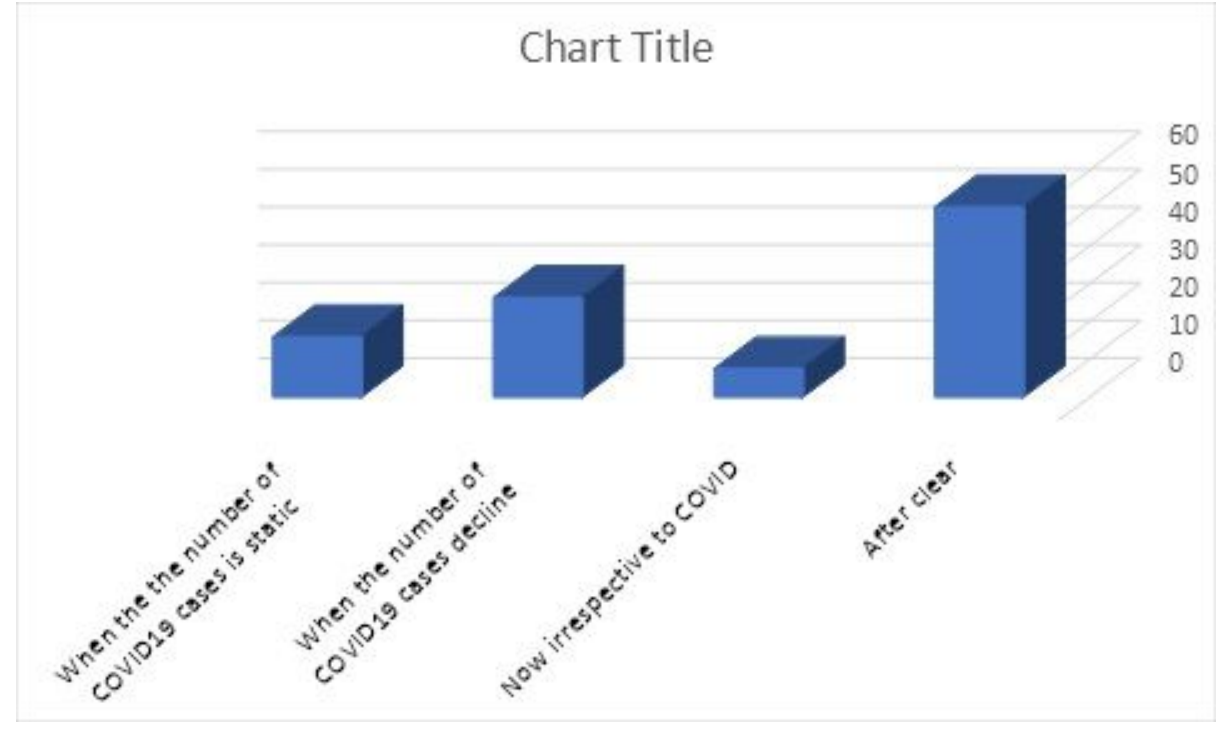

Figure 1

Students view regarding the suitable time to re-start learning process and open the University 


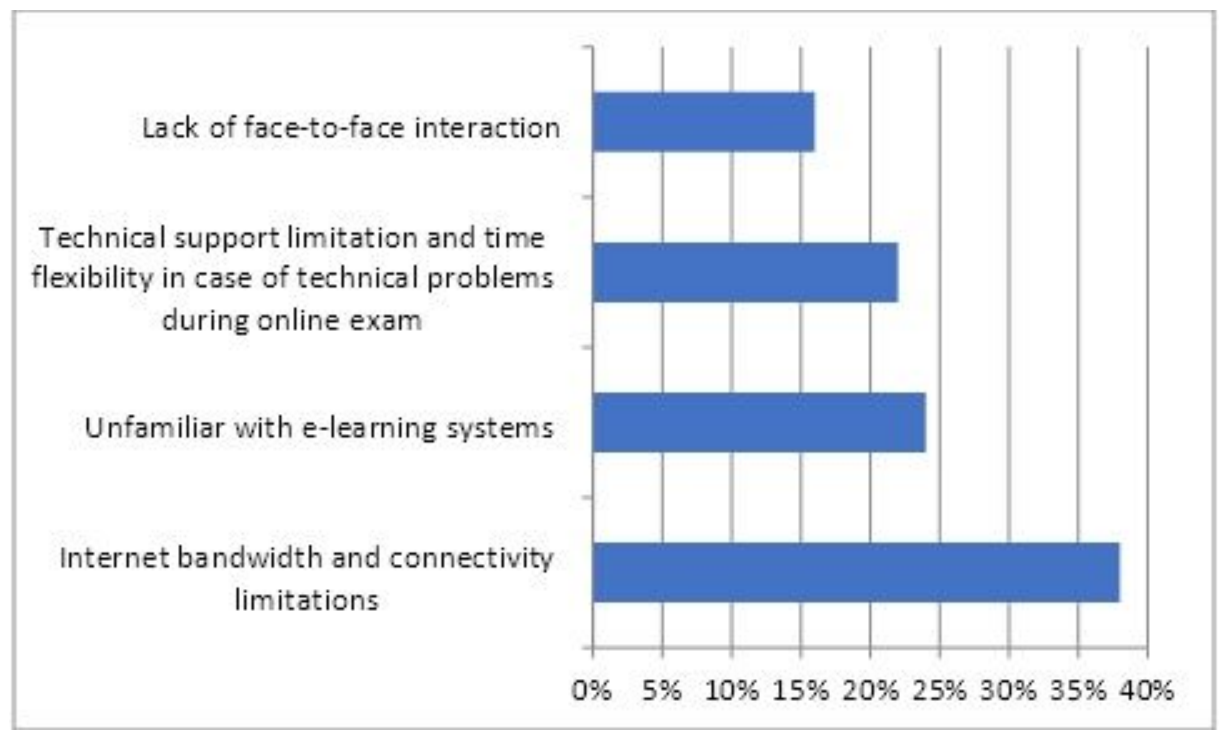

Figure 2

Students' opinions $(\mathrm{N}=358)$ regarding factors that considered being against the E-learning implementation

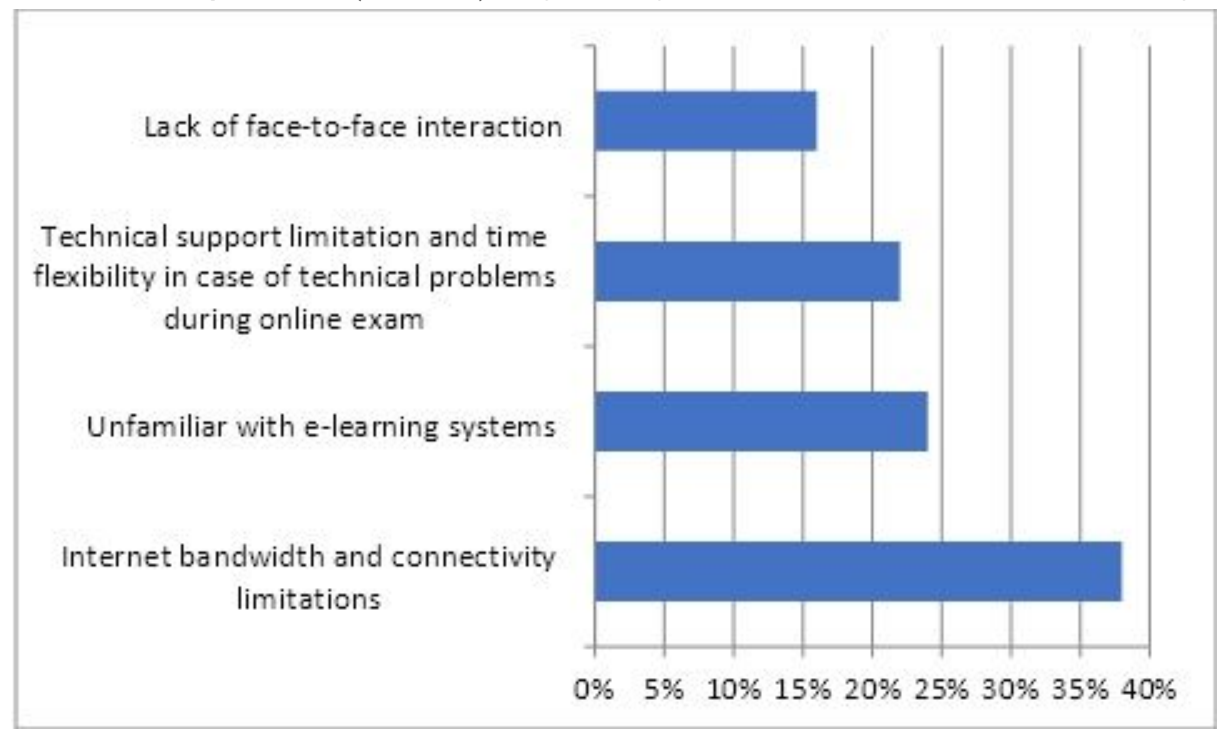

\section{Figure 2}

Students' opinions ( $\mathrm{N}=358)$ regarding factors that considered being against the E-learning implementation 